\title{
Quantitative Determination of Selenium and Mercury, and an ICP-MS Semi-Quantitative Scan of Other Elements in Samples of Eagle Tissues Collected from the Pacific Northwest-Summer, 2011
}

Data Series 755 



\section{Quantitative Determination of Selenium and Mercury, and an ICP-MS Semi- Quantitative Scan of Other Elements in Samples of Eagle Tissues Collected from the Pacific Northwest-Summer, 2011}

By Thomas May, Mike Walther, and William Brumbaugh

Data Series 755 


\title{
U.S. Department of the Interior \\ KEN SALAZAR, Secretary
}

\section{U.S. Geological Survey \\ Suzette M. Kimball, Acting Director}

\author{
U.S. Geological Survey, Reston, Virginia: 2013
}

For more information on the USGS - the Federal source for science about the Earth, its natural and living resources, natural hazards, and the environment, visit http://www.usgs.gov or call 1-888-ASK-USGS.

For an overview of USGS information products, including maps, imagery, and publications, visit http://www.usgs.gov/pubprod

To order this and other USGS information products, visit http://store.usgs.gov

Any use of trade, firm, or product names is for descriptive purposes only and does not imply endorsement by the U.S. Government.

Although this information product, for the most part, is in the public domain, it also may contain copyrighted materials as noted in the text. Permission to reproduce copyrighted items must be secured from the copyright owner.

Suggested citation:

May, T.W., Walther, M.J., and Brumbaugh, W.G., 2013, Quantitative determination of selenium and mercury, and an ICPMS semi-quantitative scan of other elements in samples of eagle tissues collected from the Pacific Northwest-Summer 2011: U.S. Geological Survey Data Series 755, 3 p. 


\section{Contents}

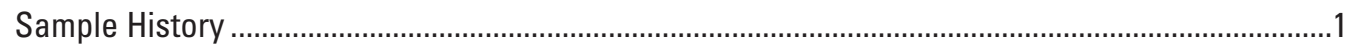

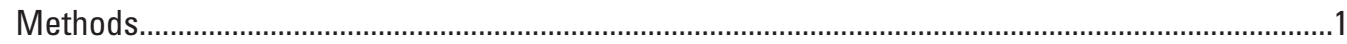

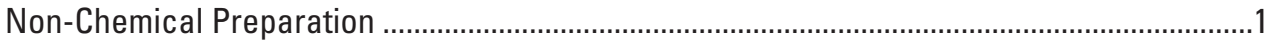

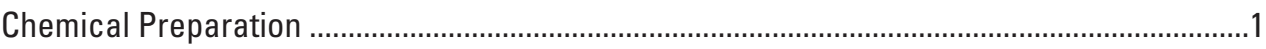

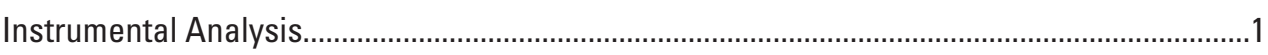

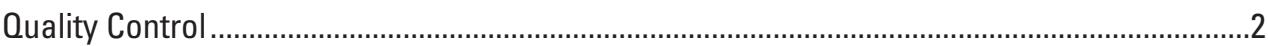

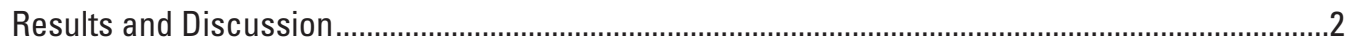

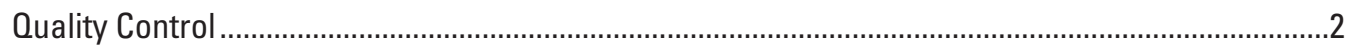

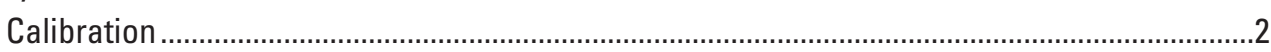

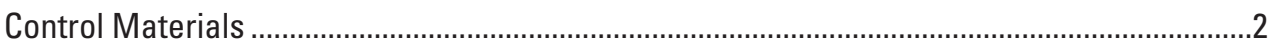

Analytical and Method Precision...........................................................................................

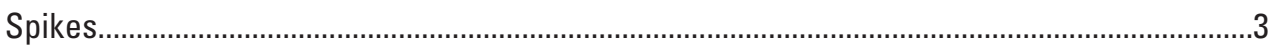

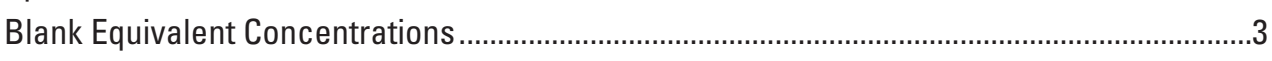

Instrument Detection, Method Detection, and Method Quantitation Limits...............................3

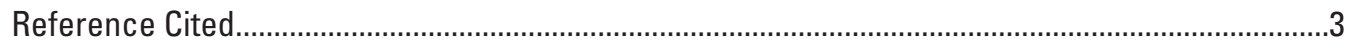





\title{
Quantitative Determination of Selenium and Mercury, and an ICP-MS Semi-Quantitative Scan of Other Elements in Samples of Eagle Tissues Collected from the Pacific Northwest-Summer, 2011
}

\author{
By Thomas May, Mike Walther, and William Brumbaugh
}

\section{Sample History}

A group of 182 eagle tissue samples was received by the inorganic section of the Columbia Environmental Research Center (CERC) on August 18, 2011, consisting of liver [number $(n)=26]$, kidney $(n=25)$, brain $(n=23)$, talon $(n=25)$, feather $(n=25)$, femur $(n=25)$, humerus $(n=25)$, and stomach contents $(n=8)$. The samples originated from frozen eagle carcasses collected from the Pacific Northwest. The sample group was assigned Batch 1936 and CERC identifications 55117-55297, and Batch 2052 for 57302. This sample collection was part of a study to document the occurrence of metal and metalloid contaminants in tissues of eagle carcasses. These tissues were to be quantitatively analyzed for concentrations of selenium (Se) and mercury $(\mathrm{Hg})$, and for other elements by semiquantitative scan (TotalQuant ${ }^{\mathrm{TM}}$ ) with an inductively coupled plasma-mass spectrometer (ICP-MS).

\section{Methods}

\section{Non-Chemical Preparation}

All eagle tissue samples were lyophilized with a Virtis Genesis $^{\mathrm{TM}}$ 35EL lyophilizer, and percent moisture was determined as part of the lyophilization process. Following lyophilization, talon, humerus, femur, feather, and stomach content samples were further homogenized by freezing them in liquid nitrogen followed by cryogenic grinding using a Spex 6850 Freezer Mill ${ }^{\mathrm{TM}}$. After cryogenic grinding, samples once again were lyophilized to remove any residual moisture obtained during grinding. Cryogenically ground samples had the appearance of a fine dry powder. Dried liver, brain, and kidney samples were placed in a glass scintillation vial and ground to a coarse powder consistency with a glass rod. All dried and homogenized samples were stored in sealed glass vials in a desiccator until time of further processing.

\section{Chemical Preparation}

To prepare digestates of talon, femur, humerus, and feather eagle tissues suitable for semi-quantitative scan by ICP-MS, an aliquot part of each dried sample, ranging from approximately 0.2 to 0.25 grams (g), was heated with a mixture of nitric acid, hydrochloric acid, and hydrogen peroxide in a sealed Teflon ${ }^{\mathrm{TM}}$ medium pressure microwave oven (Perkin-Elmer Multiwave ${ }^{\mathrm{TM}}$ ). The cooled digestate liquid was transferred into a 125 milliliter $(\mathrm{mL})$ polyethylene bottle with ultrapure water [greater than $(>) 10$ megohms per centimeter] to a final volume of $100 \mathrm{~mL}$. Final acid matrix was 6 percent nitric acid and 1 percent hydrochloric acid. Similarly, aliquots of dried brain, kidney, and liver samples (approximately $0.2 \mathrm{~g}$ ) were heated with nitric acid in a CEM MARSExpress ${ }^{\mathrm{TM}}$ microwave oven, with a final acid matrix of 6 percent nitric acid and a $100 \mathrm{~mL}$ digestate volume. An additional tissue aliquot (approximately $0.5 \mathrm{~g}$ ) of each dried tissue sample was subjected to a dry ashing procedure with a magnesium nitrate and nitric acid dry ashing procedure, followed by a hydrochloric acid reduction for the determination of Se. The dry ashing procedure consisted of three steps: boiling with nitric acid for solubilization and partial oxidation, $500{ }^{\circ} \mathrm{C}$ ashing with magnesium nitrate to complete the oxidation and decompose remaining organic matter, and heating with $\mathrm{HCl}$ to dissolve the ash and reduce $\mathrm{Se}$ to the $\mathrm{Se}^{+4}$ oxidation state required for hydride generation. Following reduction, digestates were diluted to $\sim 100 \mathrm{~mL}$ with deionized water, yielding a final acid matrix of $10 \%$ hydrochloric acid.

For the determination of $\mathrm{Hg}$ in eagle tissue samples, there was no chemical preparation (digestion) because the dried sample was thermally decomposed during the analysis (see Instrument Analysis section below).

\section{Instrumental Analysis}

To perform a scan of elements (excluding Se and $\mathrm{Hg}$ ), samples were analyzed by ICP-MS using the semi-quantitative scan mode (TotalQuant ${ }^{\mathrm{TM}}$ ). This scanning mode has a 
manufacturer's reported accuracy of +30 percent to +50 percent. All samples were diluted $10 \mathrm{X}$ by a CETAC ASD-500 autodiluter as part of the analytical sequence. Internal standards were scandium (10ppb), rhodium (10ppb), and thorium (10ppb), and the external standard consisted of an NIST traceable reference solution (Trace Metals in Drinking Water; High Purity Standards, Charleston, South Carolina) to which five elements (praseodymium, terbium, thulium, tantalum, and gold) were added for improved calibration in the rare earth region of the mass spectral range.

Mercury was determined with a direct mercury analyzer. With this method, a dried eagle tissue sample (approximately $10-80 \mathrm{mg}$ ) was combusted in a stream of oxygen. All $\mathrm{Hg}$ in the sample was volatilized and trapped by amalgamation on a gold substrate, and was thermally desorbed and quantified by atomic absorption spectrophotometry (U.S. Environmental Protection Agency, 2003). The entire sequence was conducted with a Milestone DMA-80 ${ }^{\mathrm{TM}}$ analyzer equipped with an automated sample carousel.

The determination of Se in dry-ashed samples was accomplished by flow injection hydride generation atomic absorption spectroscopy. In this procedure, the digestate is mixed with a hydrochloric acid carrier solution and then reduced by sodium tetrahydridoborate that has been stabilized with sodium hydroxide. The resulting volatile hydrogen selenide is transferred with argon carrier gas into a heated quartz cell mounted on an atomic absorption spectrophotometer for decomposition and measurement.

\section{Quality Control}

Samples were processed through the preparative and analytical flow scheme in eight analytical blocks or groups for the semi-quantitative scan, eight blocks for $\mathrm{Hg}$, and eight additional blocks for preparation of samples for Se. Each block was identified by assigning a block initiation date (BID). Quality control included in each BID depended on the final instrumental approach. For digestion of eagle tissues for the ICP-MS scan, quality control included digestion blanks, reference solutions and materials, sample replicates, and sample spikes. Quality-control parameters for sample analysis by an ICP-MS scan included running the single calibration standard as a sample, a measurement of precision by repeated runs of a reference solution, the analysis of independent-source laboratory control samples, and within-run monitoring of changes in the internal standards. For samples analyzed by atomic absorption (Se), predigestion quality control included digestion blanks, replicates, spikes, and reference solutions and materials. Analytical quality control for Se included calibration verification solutions and analysis spikes. For direct analysis of $\mathrm{Hg}$ in tissue by thermal combustion, amalgamation, and atomic absorption spectroscopy (DMA-80), quality control included calibration verification solutions, reference tissues, replicates, method spikes, and blanks. All quality-control results were tabulated to provide an overview of quality assurance and to facilitate interpretation.

\section{Results and Discussion}

Total recoverable concentrations of elements in eagle tissues, determined by ICP-MS semi-quantitative scan, are indicated in tables 1-8 in the Excel spreadsheet $d s 755$ tables. For the various tissue matrices analyzed by an ICP-MS semiquantitative scan, some elemental concentrations were quite variable within a particular matrix; notable observations were as follows: Lead concentrations ( $\mu \mathrm{g} / \mathrm{g}$ dry weight) ranged from 0.2 to 31 in femurs, 0.1 to 29 in humeri, 0.1 to 54 in talons, $<0.05$ to 120 in livers, $<0.05$ to 34 in kidneys, and 0.05 to 8 in brains; copper concentrations ( $\mu \mathrm{g} / \mathrm{g}$ dry weight) ranged from 5 to 9 in feathers, 8 to 47 in livers, 7 to 43 in kidneys, and 7 to 28 in brains; cadmium concentrations ( $\mu \mathrm{g} / \mathrm{g}$ dry weight) ranged from 0.1 to 10 in kidneys. In stomach contents, concentrations $(\mu \mathrm{g} / \mathrm{g}$ dry weight)of vanadium ranged from 0.08 to 5 , chromium 2 to 34 , manganese 1 to 57 , copper 2 to 69 , arsenic $<0.05$ to 6 , rubidium 1 to 13 , and barium $<0.5$ to 18 .

Measured concentrations of Se and $\mathrm{Hg}$ determined by quantitative atomic absorption techniques are indicated in tables 9-11 in the Excel spreadsheet $d s 755$ tables. For selenium concentrations in eagle tissues (table 9), concentrations ( $\mu \mathrm{g} / \mathrm{g}$ dry weight) from highest to lowest based on the matrix mean were as follows: kidney, liver, feather, brain, stomach content, talon, femur, and humerus. For mercury (tables 10 and 11) the highest to lowest concentrations were feather, liver, talon, brain, stomach content, femur, and humerus.

Note that the Se and $\mathrm{Hg}$ data in this report were produced using quantitative techniques, but all remaining data were produced usng a semi-quantitative technique. Because of greater imprecision and inaccuracy, any elemental values of concern found from the semi-quantitative scan require verification with a quantitative sample analysis.

\section{Quality Control}

\section{Calibration}

Periodic runs of a laboratory control solution served to monitor calibration throughout the semi-quantitative scan for fish tissue (tables 12-19 in the Excel spreadsheet $d s 755_{-}$ tables. In addition, separate calibration solutions also were analyzed at the beginning of each run, which exhibited recoveries ranging from $75 \%$ to $135 \%$ (tables 20-27 in the Excel spreadsheet $d s 755$ tables. For Se and Hg, a calibration check solution was analyzed at the beginning and end of the analytical runs (table 28 in the Excel spreadsheet $d s 755$ tables).

\section{Control Materials}

Results from the analysis of control materials are indicated in tables $29-41$ in the Excel spreadsheet $d s 755$ tables. Numerous tissue reference and research materials analyzed 
by ICP-MS semi-quantitative scan (tables 29-37) exhibited recoveries mostly ranging from $80 \%$ to $120 \%$. Poorer recoveries were evident for some materials, particularly those that contained low levels of $\mathrm{Cr}$ and $\mathrm{Pb}$. Recoveries of elements from various reference and research materials, digested and analyzed in conjunction with the determination of Se by quantitative flow injection atomic absorption spectroscopy and determination of $\mathrm{Hg}$ by thermal combustion and amalgamation atomic absorption spectroscopy, are shown in tables 38-41. Recoveries were well within $80 \%$ to $120 \%$.

\section{Analytical and Method Precision}

Analytical precision for the semi-quantitative scan on digestates of eagle tissue samples was estimated by repeated runs of a reference solution, which exhibited percent relative standard deviation ( $\%$ RSD) values of $\leq 20$ percent (tables 12-19). Internal standards differed by $\leq 31$ percent from the beginning to the end of the analytical runs (table 42 in the Excel spreadsheet ds755 tables, except for Sc in femur and humerus matrices, which exhibited more change exacerbated by high $\mathrm{Ca}$ content. Instrumental precision for $\mathrm{Se}$ and $\mathrm{Hg}$, determined by repeated analysis of a standard throughout the runs, was $<4$ percent RSD (table 43 in the Excel spreadsheet ds 755 tables. A duplicate analysis of digestates from each matrix produced relative percent differences (RPDs) of $<2$ percent (table 44 in the Excel spreadsheet $d s 755$ tables. Method precision for eagle tissues was determined by triplicate digestion and analysis of a sample (tables 45-53 in the Excel spreadsheet $d s 755$ tables). Triplicate digestion and analysis of eagle tissue samples analyzed by ICP-MS semi-quantitative scan (tables 45-52) exhibited percent RSDs generally $\leq 30$ percent for most elements in most matrices. Replicate digestion and analysis of samples for $\mathrm{Hg}$ and Se determination produced percent RSDs $\leq 13$ percent (table 53).

\section{Spikes}

Recoveries of elements spiked into eagle tissue samples prepared for the semi-quantitative scan are presented in tables 54-61 in the Excel spreadsheet $d s 755$ tables. Recoveries ranged from 80 percent to 130 percent for most elements, with the exception of higher recoveries for Be (132 percent to 160 percent), and one case of a low recovery for $\mathrm{V}$ (71 percent). Samples of eagle tissue spiked with $\mathrm{Hg}$ and $\mathrm{Se}$ exhibited recoveries ranging from 88 percent to 113 percent (tables 62 and 63 in the Excel spreadsheet ds755_tables. Recoveries of $\mathrm{Se}$ in analysis (post-digestion) spikes ranged from 97 percent to 110 percent (table 64 in the Excel spreadsheet $d s 755$ tables.

\section{Blank Equivalent Concentrations}

Blank equivalent concentrations (BEC) were computed for digestion blanks analyzed with each set of eagle tissue samples (tables 65-72 in the Excel spreadsheet $d s 755$ tables. For most elements determined by ICP-MS semi-quantitative scan, BECs generally were below the reporting limits of the semi-quantitative scan ("less than" values of $0.04,0.05,0.4$, or $0.5 \mu \mathrm{g} / \mathrm{g}$ dry weight). For those eagle tissues that were subjected to cryogenic grinding, quartz chips were ground and digested to simulate elements that might be picked up from grinding a hard material (tables 73 and 74 in the Excel spreadsheet $d s 755$ tables. Mean BECs for Se and $\mathrm{Hg}$ are indicated in tables 75 and 76 in the Excel spreadsheet ds 755 tables; all BECS were below their respective method detection limits except for one case of Se (eagle talon; $0.006 \mu \mathrm{g} / \mathrm{g}$ dry weight; table 75).

\section{Instrument Detection, Method Detection, and Method Quantitation Limits}

Instrument detection limits for Se determined by flow injection hydride generation atomic absorption spectroscopy and $\mathrm{Hg}$ by thermal combustion/amalgamation atomic absorption spectroscopy are indicated in table 77 (Excel spreadsheet ds 755 tables), whereas method detection and quantitation limits are indicated in table 78 (Excel spreadsheet $d s 755$ _tables).

Overall, quality-control results were acceptable based on specifications established by CERC.

\section{Reference Cited}

U.S. Environmental Protection Agency, 2003. Test Methods: SW-846 Manual, Draft Update IVA, 7000 Series, Method 7473, "Mercury in Solids and Solutions by Thermal Decomposition, Amalgamation, and Atomic Absorption Spectrophotometry", 17 pages, February 5, 2013, at http:// www.epa.gov/sam/pdfs/EPA-7473.pdf. 
Publishing support provided by:

Rolla Publishing Service Center

For more information concerning this publication, contact:

Director, USGS Columbia Environmental Research Center

4200 New Haven Road

Columbia, M0 65201

(573) 875-5399

Or visit the Columbia Environmental Research Center Web site at: http://www.cerc.usgs.gov/ 



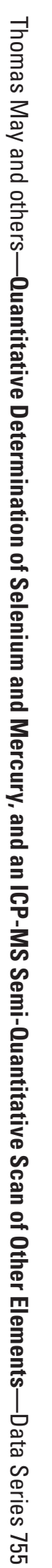

